\title{
The concept of hard coal supplies model with the inclusion of selected environmental regulations
}

ABSTRACT: The implementation of EU environmental regulations in the energy sector is challenging for the power industry of its member states. The main role is played by documents such as the Winter Package and, especially, the Directive of the European Parliament and of the Council on the emission limits of certain pollutants and the implementation of BAT conclusions in order to achieve the EU's decarbonization objectives. These regulations impose a greater need to control harmful substances emitted to the atmosphere while using fossil fuels, including hard coal, which is the main fuel for domestic units. At the same time, the decline in domestic fossil fuel production and decrease in the quality of parameters of the hard coal makes it difficult to purchase the proper fuel for power plants. As a consequence, the costs of hard coal increase. The article presents the concept of a mathematical model that can be applied for the optimization of coal supplies. The employment of this model allows one to achieve cost reductions. One of the advantages of the proposed tool, in addition to minimizing the cost of purchase and use of hard coal, is its rational management, especially for companies producing and using hard coal.

KEYWORDS: environmental regulations, BAT conclusions, mathematical modeling, energy sector, hard coal

$\checkmark$ Corresponding Author: Marcin Malec; e-mail: malec@meeri.pl

1 The Mineral and Energy Economy Research Institute of the Polish Academy of Sciences, Krakow, Poland; ORCID iD: 0000-0003-4587-9613; e-mail: malec@meeri.pl

2019. The Author(s). This is an open-access article distributed under the terms of the Creative Commons Attribution-ShareAlike International License (CC BY-SA 4.0, http://creativecommons.org/licenses/by-sa/4.0/), which permits use, distribution, and reproduction in any medium, provided that the Article is properly cited. 


\section{Introduction}

Mathematical models supporting the decision-making process are increasingly applied in the energy industry. Methods to optimize the acquisition of coal or, in the broader sense, the rational use of coal, lead directly to effective management of the production process. Examples of enterprises implementing these types of tools, contributing to the minimization of costs, increase the interest in these types of tools in the fuel and energy sector (Kamiński 2018).

Mathematical modeling has an interdisciplinary range, which is why the resulting models can become useful in almost any field. In the power industry, in the production of electricity from hard coal, the area in which this method can be applied is the acquisition of fuels characterized by quality parameters that meet the requirements necessary for the proper operation of power generation units. Under the current conditions, the applicability of the optimization model aimed at supporting the process of obtaining fuels using the mathematical programming approach should take not only the cost of supply and the choice of the appropriate quality coal into account, but also the additional costs resulting from these choices.

The decline in the production of fossil fuels and their use for electricity generation (Table 1) and the increase in ash content and harmful elements content in hard coal contribute to the fact that the selection of coal with quality parameters meeting the requirements of commercial power industry boilers is problematic. At the same time, quality parameters of the available fuels for sale are often unsatisfactory from the hard coal mining sector point of view. The essence of the problem is the increase in the content of harmful elements in the hard coals offered to the commercial power industry by the domestic producers. The consequence of the increase in these

TABLE 1. Production, consumption, and import of hard coal in Poland, 2011-2018 [million Mg]

Tabela 1. Produkcja, zużycie i import węgla kamiennego w Polsce, 2011-2018 [mln Mg]

\begin{tabular}{|c|c|c|c|c|c|c|c|c|c|}
\hline & Unit & 2011 & 2012 & 2013 & 2014 & 2015 & 2016 & 2017 & 2018 \\
\hline \multicolumn{10}{|c|}{ Hard coal consumption in Poland } \\
\hline In total & million $\mathrm{Mg}$ & 79.1 & 75.2 & 77.3 & 72.8 & 72.3 & 74.2 & 76.1 & - \\
\hline Including thermal coal & million $\mathrm{Mg}$ & 71.6 & 64.4 & 66.2 & 61.0 & 58.4 & 61.0 & 62.9 & - \\
\hline \multirow{2}{*}{ In public power plants } & million $\mathrm{Mg}$ & 43.8 & 40.4 & 40.7 & 37.6 & 36.6 & 38.5 & 39.0 & - \\
\hline & $\%$ & $61 \%$ & $63 \%$ & $61 \%$ & $62 \%$ & $63 \%$ & $63 \%$ & $62 \%$ & - \\
\hline \multicolumn{10}{|c|}{ Hard coal production in Poland } \\
\hline In total & million $\mathrm{Mg}$ & 75.7 & 79.2 & 76.5 & 72.5 & 72.2 & 70.4 & 65.5 & 63.4 \\
\hline Including thermal coal & million $\mathrm{Mg}$ & 64.2 & 67.5 & 64.4 & 60.2 & 59.2 & 57.2 & 53.0 & 51.3 \\
\hline \multicolumn{10}{|c|}{ Import of hard coal in Poland } \\
\hline In total & million $\mathrm{Mg}$ & 15.0 & 10.2 & 10.5 & 10.3 & 8.2 & 8.3 & 10.1 & 14.6 \\
\hline Including thermal coal & million $\mathrm{Mg}$ & 12.7 & 8.6 & 8.3 & 7.9 & 5.5 & 6.1 & 7.3 & 12.3 \\
\hline
\end{tabular}

Source: own study based on (ARE 2018; ARP 2018; GUS (Statistics Poland) 2018). 
parameters are costs related to the use of hard coal in the power industry. It is necessary to consider the possibility of reducing these costs through the appropriate selection of fuel already at the stage of supply planning.

The topicality of the discussed issue depends on lowering the permissible concentration of harmful substances and the imposition of limits on new substances resulting from the need to implement the BAT conclusions. Obliging power plants to comply with the emission limits makes it necessary to take greater number of factors related to the relevant quality parameters of the coal when selecting a fuel into account; this, in turn, triggers the need to optimize supplies in the context of costs related to hard coal combustion.

A number of studies on the optimization of hard coal supplies are focused on the objective of minimizing the cost of supply (Jeng-Wen et al. 2017), i.e. the possibility of choosing the best conditions for transporting coal, mainly in the Pacific region. Many publications in this field (Liu 2008; Yucekaya 2013; Kamiński and Saługa 2014; Yucekaya 2015; Suwała 2015; Huang and Wu 2016) present the usage of optimization models in purchasing strategies for energy enterprises. However, these models only take the basic quality parameters of coal and the cost of its delivery into account. Models investigating the optimal distribution of coal in Poland are also focused on ensuring the availability of coal that meets the basic quality criteria (Fałtyn and Naczyński 2018).

The purpose of the article is to identify key parameters affecting the costs of hard coal, which should be kept in mind while obtaining the coal and the presentation of the conceptual mathematical model supporting the decision-making process in this area. The security of supplies (through purchase or own- production) and the appropriate selection of coal used in power generating units under stricter emission limits and the necessity to pay environmental fees requires in-depth analyzes of possible directions of coal supplies.

The first chapter of this paper shows crucial qualitative parameters of coal, which need to be taken into account by its consumers (public power plants) in the hard coal trading process. The second chapter presents key environmental regulations affecting coal's purchase. The goal of the mathematical model and dependencies between elements of the system were shown in the third chapter. As a summary, the key elements of the model concept were discussed and the direction of further research was indicated.

\section{The importance of quality parameters in hard coal trade}

In coal trade, the parameters affecting the price of the obtained coal are: $Q[\mathrm{~kJ} / \mathrm{Mg}]$ - calorific value, $S[\%]$ - sulfur content, $A[\%]$ - ash content; however, as of today, only the calorific value and sulfur content are of great importance, while the ash content is agreed between the contractors. However, due to the consequences of their use in generating units, other quality parameters 
are also of importance. These parameters affect a number of additional costs related to the use of coal in the energy sector, such as emission costs, costs of $\mathrm{CO}_{2}$ emissions, costs of waste management, or renovation and maintenance costs. Therefore, it is also important to maintain additional parameters in the defined ranges affecting the functioning of the entire technological system, i.e. moisture content $W_{t}^{r}[\%]$, sinterability determined by the Roga index (RI) [-], $\mathrm{Cl}$ content [\%], $\mathrm{Hg}$ content [ppm], $\mathrm{F}$ content [\%], B content [\%], grain size [mm], transportability and grindability (Róg 2010; Grudziński 2011).

The power plants require fuels that meet the technical requirements of boilers. However, it should be borne in mind that the boilers put into operation several years ago were often designed for dedicated coal from a mine located near the generating unit. In the age of moving away from coal, there is a problem with providing coal of adequate quality. In addition, the manufacturers strive to ensure the so-called optimal fuel parameters; the use of such fuel does not translate into higher operating costs, frequent maintenance, and repairs. What is more, poor quality fuel causes problems with waste management and contributes to the increased emission of harmful substances. To avoid this, environmentally-friendly installations are being built and modernized, which requires additional capital expenditures.

In order to reduce these costs, looking for coal with the best parameters is expected; therefore, it is reasonable to take the possibility of reducing these costs already at the stage of supply planning, which is not the practice of generating units, into account.

\section{Environmental regulations - the need to meet quality requirements and fuel costs}

Apart from the market (coal price) and technological (optimal parameters for boilers) conditions, the selection of coal for generating units is closely dependent on the environmental regulations adopted at the international level that are directly affecting the energy sector and, indirectly, the hard coal mining sector. In particular, this applies to policies aimed at EU decarbonization.

\subsection{The climate and energy package}

The climate and energy package $(3 \times 20 \%$ package) was agreed by EU leaders in 2007 . The package sets three key targets: a $20 \%$ cut in greenhouse gas emissions, $20 \%$ of renewables in the energy-mix, and a $20 \%$ improvement in energy efficiency. The package includes both EU-wide and national targets taken on by member states. 
The second stage of the climate and energy package, for the years 2021-2030, was set in 2014. The global objectives adopted for this period for the entire European Union include the reduction of greenhouse gas emissions by $40 \%$ (compared to 1990) and a $27 \%$ share of renewables (Wojtkowska-Łodej 2014; Malec et al. 2016; Wojtkowska-Łodej and Nyga-Łukaszewska 2018).

These objectives were revised in November 2016 by the so-called Winter Package, most important assumptions of which are:

\ EU Decarbonization - reduction of greenhouse gas emissions by $40 \%$ to 2030 by, among others, introducing a $\mathrm{CO}_{2}$ emission limit for electricity generation at a level of $550 \mathrm{~g}$ $\mathrm{CO}_{2} / \mathrm{kWh}$.

$\downarrow$ Renewable energy target for the EU for 2030 of at least $32 \%$.

$\checkmark$ An energy efficiency target for the EU for 2030 of $32.5 \%$.

The key regulation for the Polish power industry is the need to meet the emission limits, set in the BAT conclusions (Best Available Techniques), for hard coal and lignite combustion.

\subsection{BAT conclusions}

Meeting the requirements of Directive 2010/75/EU on industrial emissions (the so-called IED Directive) when it comes to the new fuel emission standards is a major challenge for the Polish electricity generation sector, which is largely based on hard coal and lignite-fired units. This indirectly affects the demand for these primary energy carriers as well as their quality. This is a key issue for plant owners who have had or will have to decommission or modernize the existing units or invest in new generation units in the near future. This is in line with the Directive 2010/75/EU: each installation should operate only if it holds a permit; all installations must apply the Best Available Techniques (BATs). This is due to the need to harmonize emission standards between industrial sectors in EU countries. Therefore, BAT reference documents were prepared for all sectors covered by the IED Directive. Then, after drawing up and reviewing BREFs, BAT conclusions' were produced for every BREF. BAT conclusions are mandatory in the permitting/licensing process.

The Commission Implementing Decision (EU) 2017/1442 of July 31, 2017 establishing best available techniques (BAT) conclusions for large combustion plants was published on August 17, 2017. The large combustion plants (LCP) should adapt to the standards set out in the BAT Conclusions by August 17, 2021, i.e. four years after the publication of the said document (BAT Conclusions 2017).

The adopted requirements for the power sector, specifically for large combustion sources, are based on the final version of the BAT reference document (BREF LCP 2016) published in June 2016. It is expected that the emission limits will be being continuously tightened Table 2 compare emissions for $\mathrm{SO}_{2}, \mathrm{NO}_{\mathrm{x}}, \mathrm{PM}$ from large hard coal-fired combustion plants, meeting the requirements of the BAT conclusions, with the emission limits set by the IED. 
TABLE 2. The comparison of $\mathrm{SO}_{2}$ emission standards for new and existing hard coal-fired plants

TABELA 2. Porównanie norm emisji tlenków siarki $\mathrm{SO}_{2}$ dla nowych i istniejących źródeł spalania paliw stałych (węgiel kamienny)

\begin{tabular}{|c|c|c|c|c|}
\hline \multirow{2}{*}{$\begin{array}{c}\text { The total rated } \\
\text { thermal input of } \\
\text { the combustion } \\
\text { plant }\end{array}$} & \multicolumn{2}{|c|}{ BAT-AELs } & \multicolumn{2}{c|}{ Directive 2010/75/EU (IED) } \\
\cline { 2 - 5 } $\mathrm{MW}_{\text {th }}$ & existing plant & new plant & existing plant & new plant \\
\hline $50-100$ & $150-360$ & $150-200$ & 400 & 400 \\
\hline $100-300$ & $95-200$ & $80-150$ & 250 & 200 \\
\hline & $\begin{array}{c}10-130 \\
\text { pulverized-coal-fired } \\
\text { boiler }\end{array}$ & $\begin{array}{c}10-75 \\
\text { pulverized-coal-fired } \\
\text { boiler }\end{array}$ & 200 & 150 \\
\cline { 2 - 5 } & $\begin{array}{c}20-180 \\
\text { fluidized bed coal fired } \\
\text { boiler }\end{array}$ & $\begin{array}{c}20-75 \\
\text { fluidized bed coal } \\
\text { fired boiler }\end{array}$ & 200 & $\begin{array}{c}\text { (yearly average) } \\
\text { fluidized bed coal } \\
\text { fired boiler }\end{array}$ \\
\hline
\end{tabular}

Source: own study based on (BAT Conclusions 2017 and Directive 2010).

TABLE 3. The comparison of $\mathrm{NO}_{\mathrm{x}}$ emission standards for new and existing hard coal-fired plants

TABELA 3. Porównanie norm emisji tlenków azotu $\mathrm{NO}_{\mathrm{x}}$ dla nowych i istniejących źródeł spalania paliw stałych (węgiel kamienny)

\begin{tabular}{|c|c|c|c|c|}
\hline \multirow{2}{*}{$\begin{array}{c}\text { The total rated } \\
\text { thermal input of } \\
\text { the combustion } \\
\text { plant }\end{array}$} & \multicolumn{2}{|c|}{ BAT-AELs } & \multicolumn{2}{c|}{ Directive 2010/75/EU (IED) } \\
\cline { 2 - 5 } & existing plant & new plant & existing plant & new plant \\
\hline $\mathrm{MW}_{\text {th }}$ & & $\mathrm{mg} / \mathrm{Nm}^{3}$ (yearly average) & 300 \\
\hline $50-100$ & $100-270$ & $100-150$ & 300 & 200 \\
\hline $100-300$ & $100-180$ & $50-100$ & 200 & 150 \\
\hline \multirow{3}{*}{$>300$} & $\begin{array}{c}65-150 \\
\text { coal-fired PC boiler }\end{array}$ & $\begin{array}{c}65-85 \\
\text { coal-fired PC boiler }\end{array}$ & $\begin{array}{c}50-85 \\
85-150\end{array}$ \\
\cline { 2 - 5 } & $\begin{array}{c}50-800 \\
\text { fluidized bed coal fired } \\
\text { boiler }\end{array}$ & $\begin{array}{c}\text { fluidized bed coal } \\
\text { fired boiler }\end{array}$ & 200 & 150 \\
\hline
\end{tabular}

Source: own study based on (BAT Conclusions 2017 and Directive 2010).

In addition to emission limits for sulfur dioxide, nitrogen oxides, and PM, the BAT reference document for large combustion sources also provides for monitoring and emission limit values for many other compounds, including: carbon monoxide $(\mathrm{CO})$, ammonia $\left(\mathrm{NH}_{3}\right)$, nitrous oxide $\left(\mathrm{N}_{2} \mathrm{O}\right)$, while special attention is paid to mercury $(\mathrm{Hg})$, hydrogen chloride $(\mathrm{HCl})$, or hydrogen fluoride (HF), as shown in Tables 5, 6, and 7. Meeting these requirements can be a big problem, especially for units equipped with fluidized bed boilers. 
TABLE 4. The comparison of dust emission standards for new and existing hard coal-fired plants

TABELA 4. Porównanie norm emisji pyłu dla nowych i istniejących źródeł spalania paliw stałych (węgiel kamienny)

\begin{tabular}{|c|c|c|c|c|}
\hline \multirow{2}{*}{$\begin{array}{c}\text { The total rated } \\
\text { thermal input of the } \\
\text { combustion plant }\end{array}$} & \multicolumn{2}{|c|}{ BAT - AELs } & \multicolumn{2}{c|}{ Directive 2010/75/EU (IED) } \\
\cline { 2 - 5 } & existing plant & new plant & existing plant & new plant \\
\hline $\mathrm{MW}_{\text {th }}$ & & $\mathrm{mg} / \mathrm{Nm}^{3}$ (yearly average) \\
\hline $50-100$ & $2-18$ & $2-5$ & 30 & 20 \\
\hline $100-300$ & $2-14$ & $2-5$ & 25 & 20 \\
\hline $300-1000$ & $2-10$ & $2-5$ & 20 & 10 \\
\hline$>1000$ & $2-8$ & $2-5$ & 20 & 10 \\
\hline
\end{tabular}

Source: own study based on (BAT Conclusions 2017 and Directive 2010).

TABLE 5. The comparison of $\mathrm{HCl}$ emission standards for new and existing hard coal-fired plants

TABELA 5. Porównanie norm emisji $\mathrm{HCl}$ dla nowych i istniejących źródeł spalania paliw stałych (węgiel kamienny)

\begin{tabular}{|c|c|c|}
\hline \multirow{2}{*}{$\begin{array}{c}\text { The total rated thermal input } \\
\text { of the combustion plant }\end{array}$} & \multicolumn{2}{|c|}{ BAT - AELs } \\
\cline { 2 - 3 } & existing plant & new plant \\
\hline $\mathrm{MW}_{\text {th }}$ & \multicolumn{2}{|c|}{$\mathrm{mg} / \mathrm{Nm}^{3}$ (yearly average) } \\
\hline$<100$ & $2-10$ & $1-6$ \\
\hline$>100$ & $1-5$ & $1-3$ \\
\hline
\end{tabular}

Source: own study based on (BAT Conclusions 2017).

TABLE 6. The comparison of HF emission standards for new and existing hard coal-fired plants

TABela 6. Porównanie norm emisji HF dla nowych i istniejących źródeł spalania paliw stałych (węgiel kamienny)

\begin{tabular}{|c|c|c|}
\hline \multirow{2}{*}{$\begin{array}{c}\text { The total rated thermal input } \\
\text { of the combustion plant }\end{array}$} & \multicolumn{2}{|c|}{ BAT - AELs } \\
\cline { 2 - 3 } & existing plant & new plant \\
\hline MW $_{\text {th }}$ & \multicolumn{2}{|c|}{$\mathrm{mg} / \mathrm{Nm}^{3}$ (yearly average) } \\
\hline$<100$ & $<1-6$ & $<1-3$ \\
\hline$>100$ & $<1-3$ & $<1-2$ \\
\hline
\end{tabular}

Source: own study based on (BAT Conclusions 2017).

In addition to the need to adapt the generating units to meet the requirements of the BAT conclusions at the stage of obtaining coal, it is necessary to consider the costs of hard coal combustion. The key cost elements are the cost of $\mathrm{CO}_{2}$ emission allowances (Fig. 1) which have noticeably increased recently and emission charges (Tab. 8). 
TABLE 7. The comparison of $\mathrm{Hg}$ emission standards for new and existing hard coal-fired combustion plants

TABELA 7. Porównanie norm emisji Hg dla nowych i istniejących źródeł spalania paliw stałych (węgiel kamienny)

\begin{tabular}{|c|c|c|}
\hline \multirow{2}{*}{$\begin{array}{c}\text { The total rated thermal input } \\
\text { of the combustion plant }\end{array}$} & \multicolumn{2}{|c|}{ BAT - AELs } \\
\cline { 2 - 3 } & existing plant & new plant \\
\hline $\mathrm{MW}_{\text {th }}$ & \multicolumn{2}{|c|}{$\mathrm{mg} / \mathrm{Nm}^{3}$ (yearly average) } \\
\hline$<300$ & $<1-9$ & $<1-3$ \\
\hline$>300$ & $<1-4$ & $<1-2$ \\
\hline
\end{tabular}

Source: own study based on (BAT Conclusions 2017).

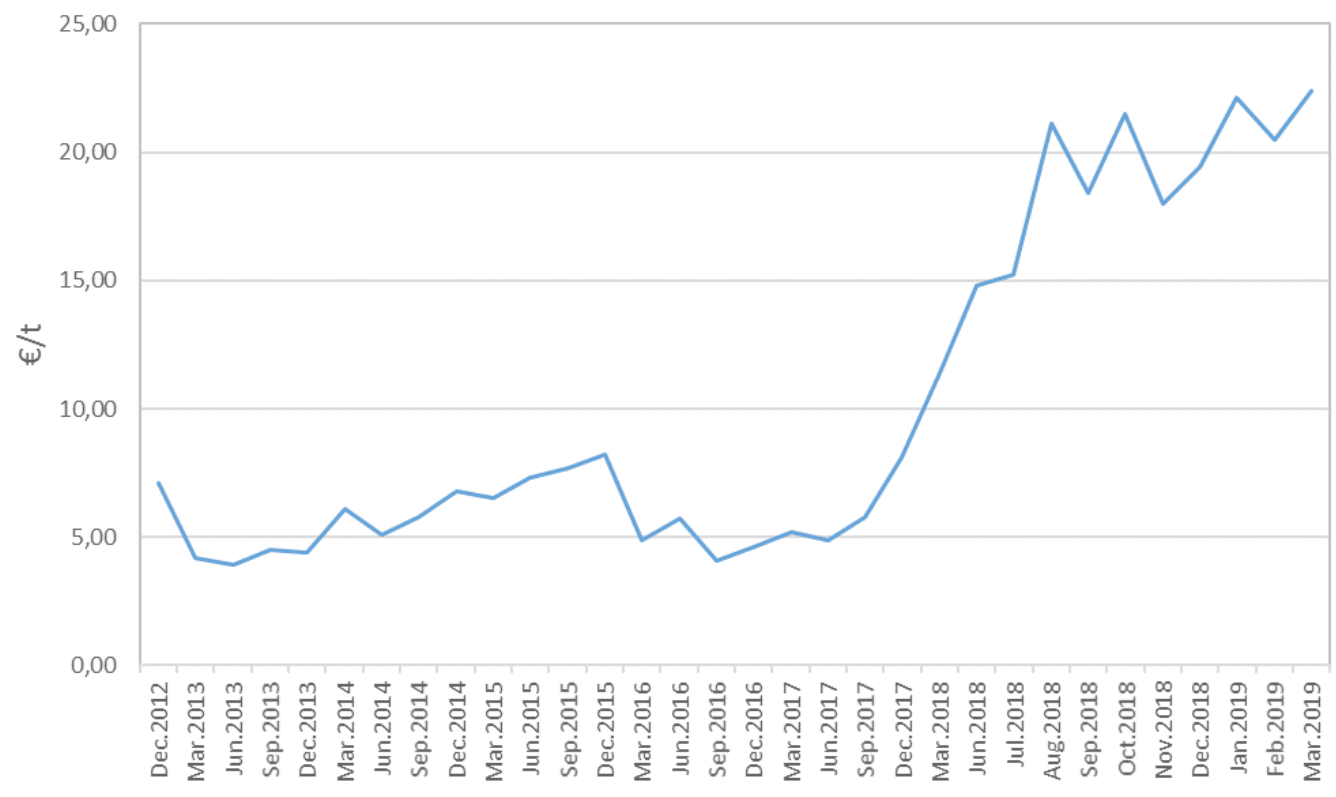

Fig. 1. Prices of $\mathrm{CO}_{2}$ emission allowances [EUR/t] (2011-2019)

Source: own study based on (CIRE 2019)

Rys. 1. Ceny uprawnień do emisji $\mathrm{CO}_{2}[\mathrm{EUR} / \mathrm{t}](2011-2019)$ 
TABLE 8. Fees for emission of harmful substances to the environment 2005-2019 [PLN/Mg]

TABELA 8. Stawki opłat jednostkowych za emisje substancji szkodliwych, 2005-2019 [PLN/Mg]

\begin{tabular}{|c|c|c|c|c|c|c|}
\hline Emissions & Unit & 2005 & 2009 & 2013 & 2017 & 2019 \\
\hline Dust & PLN/Mg & 0.27 & 0.3 & 0.34 & 0.35 & 0.36 \\
\hline $\mathrm{SO}_{2}$ & $\mathrm{PLN} / \mathrm{Mg}$ & 0.41 & 0.44 & 0.51 & 0.53 & 0.54 \\
\hline $\mathrm{NOx}$ & $\mathrm{PLN} / \mathrm{Mg}$ & 0.41 & 0.44 & 0.51 & 0.53 & 0.54 \\
\hline $\mathrm{CO}_{2}$ & $\mathrm{PLN} / \mathrm{Mg}$ & 0.22 & 0.24 & 0.28 & 0.29 & 0.3 \\
\hline $\mathrm{CO}$ & $\mathrm{PLN} / \mathrm{Mg}$ & 0.11 & 0.11 & 0.11 & 0.11 & 0.11 \\
\hline $\begin{array}{c}\text { Waste disposal } \\
\text { costs }\end{array}$ & $\mathrm{PLN} / \mathrm{Mg}$ & 13.69 & 16.95 & 18.77 & 19.64 & 20.03 \\
\hline
\end{tabular}

Source: own study based on (Ministry of the Environment 2019).

\section{The purpose of mathematical model, the concept of mapping of dependencies between elements of the system}

The dependencies presented in the previous chapters were used to develop the concept of a mathematical model aimed at the optimization of coal supplies to power generating units of the public power industry enabling a quantitative assessment of the impact of implementation of selected environmental regulations on the total costs of coal supplies to generating units, including costs resulting from its combustion. The developed research tool will enable a quantitative assessment of the impact of quality parameters of hard coal on the supply, operation, and emission costs. At the same time, the model results will allow for an estimation of the potential for use of domestic hard coal in the context of increasing quality requirements of the public power industry.

The presented concept of a mathematical model for long-term planning of hard coal supplies to the power plant reflects key relations between the hard coal mining sector and the energy sector in the context of hard coal supplies and takes into account the demand for coal and the environmental and operating costs. The developed mathematical model is a linear programming model. It will be implemented with the employment of General Algebraic Modeling System (GAMS).

On the supply side, each product (steam coal grade with specific quality parameters appropriate for a given mine/mining area) offered to the Polish market (public power industry) by coal companies (Polska Grupa Górnicza Sp. z o.o., Lubelski Węgiel Bogdanka SA, Jastrzębska Spółka Węglowa SA, Tauron Wydobycie SA, PG Silesia Sp. z o.o., ZG Siltech Sp.z o.o. and EKO-Plus Sp. z o.o.) (see Tab. 9), intermediaries offering coal with improved, parameters, and importers (hard coal for electricity production), will be identified. The price will be different for each product according to the commercial rules in the hard coal market. The level of availability 
of a given product will depend on the mine/mining area, mining capacity, processing capacity of intermediaries, and coal imports from particular countries at available border crossings (sea and land border crossings).

TABLE 9. Characteristics of the hard coal offered by the supplier - an example

TABELA 9. Przykładowa charakterystyka oferowanego węgla kamiennego w katalogu dostawcy

\begin{tabular}{|c|c|c|c|c|c|c|c|c|c|c|c|c|c|c|}
\hline $\begin{array}{c}\text { Mine } \\
{[-]}\end{array}$ & $\begin{array}{c}\text { Mining } \\
\text { area } \\
{[-]}\end{array}$ & $\begin{array}{c}\text { Assortment } \\
{[-]}\end{array}$ & $\begin{array}{c}\text { Class } \\
{[-]}\end{array}$ & $\begin{array}{c}\text { Type } \\
{[-]}\end{array}$ & $\begin{array}{c}\mathrm{Q}_{\max } \\
{[\mathrm{MJ} / \mathrm{kg}]}\end{array}$ & $\begin{array}{c}\mathrm{A}_{\max } \\
{[\%]}\end{array}$ & $\begin{array}{c}\mathrm{S}_{\max } \\
{[\%]}\end{array}$ & $\begin{array}{c}\mathrm{W}_{\text {avg }} \\
{[\%]}\end{array}$ & $\begin{array}{c}\mathrm{Cl}_{\text {avg }} \\
{[\%]}\end{array}$ & $\begin{array}{c}\mathrm{Hg}_{\text {avg }} \\
{[\mathrm{ppm}]}\end{array}$ & $\begin{array}{c}\mathrm{F}_{\text {avg }} \\
{[\%]}\end{array}$ & $\begin{array}{c}\mathrm{B}_{\text {avg }} \\
{[\%]}\end{array}$ & $\begin{array}{c}\text { Grain } \\
\text { size } \\
{[\mathrm{mm}]}\end{array}$ & $\begin{array}{c}\text { ROGI } \\
\text { Index } \\
{[-]}\end{array}$ \\
\hline KWK1 & - & MII & $22-23-08$ & 32.1 & 22 & 23 & 0,8 & 10 & 0,25 & 0,09 & 0,015 & $<0,015$ & $0-20$ & 30 \\
\hline
\end{tabular}

Source: own source.

On the demand side, power plants (implemented at the level of individual units) and public hard coal-fired combined heat and power plants will be determined. The characteristics of each unit should include the volume of fuel demand (demand for chemical energy), required quality parameters of the unit, including the optimal fuel (Tab. 10), and the available environmental installations.

TABLE 10. Coal quality parameters for a power generating unit - an example

TABELA 10. Parametry jakościowe paliwa dla jednostki wytwórczej, wartości graniczne - przykład

\begin{tabular}{|c|c|c|c|c|c|c|c|c|c|c|c|c|c|c|}
\hline \multirow{2}{*}{$\begin{array}{c}\text { Installed } \\
\text { capacity } \\
{[\mathrm{MW}]}\end{array}$} & \multirow{2}{*}{$\begin{array}{c}\text { Type of } \\
\text { coal } \\
{[-]}\end{array}$} & \multicolumn{2}{|c|}{$Q$} & \multicolumn{2}{|c|}{ A } & \multicolumn{2}{|c|}{ S } & \multirow{2}{*}{$\begin{array}{l}\mathrm{W} \\
\max \\
{[\%]}\end{array}$} & \multirow{2}{*}{$\begin{array}{c}\mathrm{Cl} \\
\max \\
{[\%]}\end{array}$} & \multirow{2}{*}{$\begin{array}{c}\mathrm{Hg} \\
\max \\
{[\%]}\end{array}$} & \multirow{2}{*}{$\begin{array}{c}\mathrm{F} \\
\max \\
{[\%]}\end{array}$} & \multirow{2}{*}{$\begin{array}{c}\mathrm{B} \\
\max \\
{[\%]}\end{array}$} & \multirow{2}{*}{$\begin{array}{c}\begin{array}{c}\text { Grain } \\
\text { size }\end{array} \\
\max \\
{[\mathrm{mm}]}\end{array}$} & \multirow{2}{*}{$\begin{array}{c}\begin{array}{c}\text { ROGI } \\
\text { Index }\end{array} \\
\max \\
{[-]}\end{array}$} \\
\hline & & $\begin{array}{c}\min \\
{[\mathrm{MJ} \cdot \mathrm{kg}]}\end{array}$ & $\begin{array}{c}\max \\
{[\mathrm{MJ} . \mathrm{kg}]}\end{array}$ & $\begin{array}{c}\min \\
{[\mathrm{MJ} . \mathrm{kg}]}\end{array}$ & $\begin{array}{c}\max \\
{[\mathrm{MJ} \cdot \mathrm{kg}]}\end{array}$ & $\begin{array}{c}\min \\
{[\mathrm{MJ} . \mathrm{kg}]}\end{array}$ & $\begin{array}{c}\max \\
{[\mathrm{MJ} . \mathrm{kg}]}\end{array}$ & & & & & & & \\
\hline 200 & 31.32 & 10.5 & 22 & 14 & 20 & 0,8 & 1,3 & 20 & 0.11 & 0.28 & 0.15 & 0.02 & $0-20$ & 40 \\
\hline
\end{tabular}

Source: own source.

The matrix of available relations between the demand and supply sides will be used to calculate the costs of coal transport while taking the type of transport into account (rail, sea, and road transport). The model parameters also include unit costs of emissions of harmful substances, costs of $\mathrm{CO}_{2}$ emission allowances and costs of unit operation resulting from not using the optimal fuel (still within the limit values).

Figure 2 shows the conceptual model. There are suppliers offering coal on the supply side (Suppliers), power plants and cogeneration plants on the demand side (Recipients); both groups are characterized by individual parameters (Input Data). The concept is complemented by optimized values (Variables), constrains, and objective function.

The results of the model will indicate the optimal level of hard coal supplies that meets the limit values of parameters in terms of individual quality parameters. Next there will be the transport costs of the purchased coal, calculated individually for each unit. At the same time, the costs of use of fuel, the emission charges incurred, and the estimated costs of overhauls/upgrades 


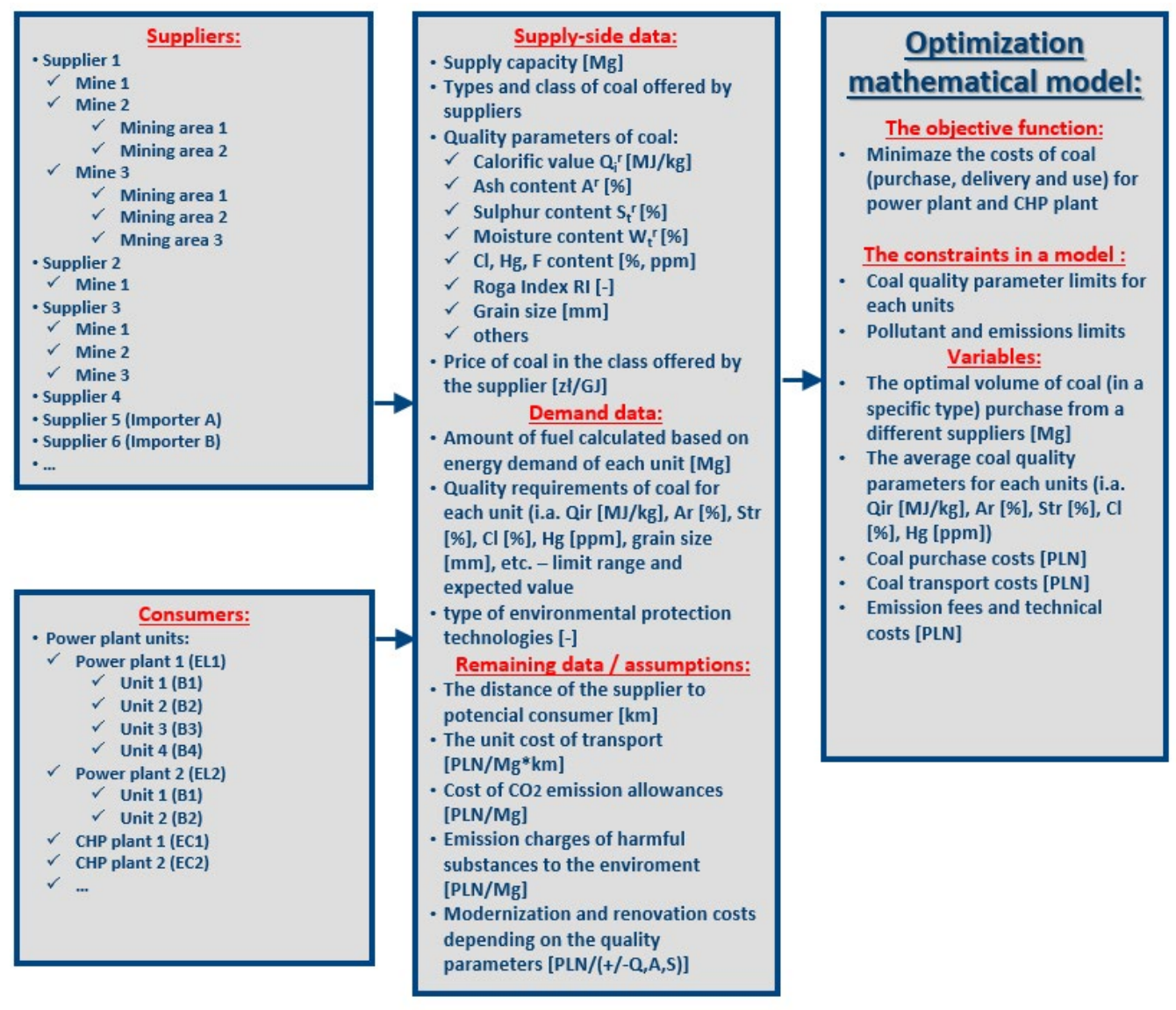

Fig. 2. Diagram - a simplified concept of a mathematical model Source: own source

Rys. 2. Schemat - uproszczona koncepcja modelu matematycznego

resulting from the use of non-optimal fuel will be indicated. The time horizon of the model is 2021-2030, with one-year time resolution.

\section{Conclusions and direction of further research}

The aim of the paper was to present the concept of a mathematical model, the role of which is to optimize coal purchases for power generating units and to support decision aim processes in order to reduce the costs associated with the use of hard coal at the stage of planning coal 
purchases. The concept of the model takes the limitations related to the need to use fuel of an appropriate quality, as well as emission limits and costs associated with fuel combustion into account. The aspects of the domestic fuel and energy sector, namely the availability of coal of appropriate quality from both domestic and import sources, the ability to meet the requirements of generating units, and the selection of fuel of appropriate quality, are taken into account.

The model will be open for modification, which will allow both the model assumptions and the input data to be adjusted depending on the changing market conditions. An important stage of the research is the transformation of the conceptual model into a mathematical model, namely set of equations, inequalities and balances, which, combined with the implementation in the modeling environment, importing input data, and developing research scenarios, provides the solution of the research problem.

The work was carried out as part of the statutory activity of the Mineral and Energy Economy Research Institute Polish Academy of Sciences.

\section{References}

Arigoni et al. 2017 - Arigoni, A., Newman, A., Turner, C. and Kaptur, C. 2017. Optimizing global thermal coal shipments. Omega Vol. 72, Issue C, pp. 118-127.

ARE 2018. Polish Power Industry Statistics (Statystyka Elektroenergetyki Polskiej) 2014-17, ARE (Energy Market Agency), Warsaw 2015-18.

BAT Conclusions 2017. Commission Implementing Decision (EU) 2017/1442 of 31 July 2017 establishing best available techniques (BAT) conclusions, under Directive 2010/75/EU of the European Parliament and of the Council, for large combustion plants (notified under document $\mathrm{C}(2017)$ 5225) [Online] https://eur-lex.europa.eu/legal-content/EN/TXT/?qid=1503383091262\&uri=CELEX:32017D1442 [Accessed: 2019-04-05].

CIRE 2019. Ceny uprawnień do emisji $\mathrm{CO}_{2}$ (Prices of $\mathrm{CO}_{2}$ emission allowances) (2012-2019) [Online] https://handel-emisjami-co2.cire.pl/st,34,514,me,0,0,0,0,0,ceny-uprawnien-do-emisji-co $2 . h t m l$ [Accessed: 2019-04-05].

Directive 2010. Directive 2010/75/EU of the European Parliament and of the Council of 24 November 2010 on industrial emissions (integrated pollution prevention and control) [Online] https://eur-lex.europa.eu/ legal-content/EN/TXT/?uri=celex\%3A32010L0075 [Accessed: 2019-04-05].

ARP (Industrial Development Agency JSC) 2018. Information on the situation of the steam coal market in Poland (Sygnalna informacja o sytuacji na rynku węgla energetycznego w Polsce) (in Polish), Katowice 2014-19.

FAŁTYN, M. and NACZYŃSKi, D. 2018. The factors shaping the demand, supply, and prices on the hard coal market. Modeling of possible changes in the long-term horizon. Polityka Energetyczna-Energy Policy Journal Vol. 21, Issue 3, pp. 47-68.

GRUDZIŃSKi Z. 2011. The impact of environmental charges influenced by coal quality on electricity production costs (Wpływ optat środowiskowych wynikających z parametrów jakościowych węla na koszty produkcji energii elektrycznej). Gospodarka Surowcami Mineralnymi - Mineral Resources Management Vol. 27, Issue 1, pp. 115-127 (in Polish). 
GUS 2018. Fuel and energy economy in the years 2016-2017 (Gospodarka Paliwowo-Energetyczna w latach 2016-2017), GUS (Statistics Poland), Warszawa 2018.

HuANG, Y.-H. and WU J.-H., 2016. A portfolio theory based optimization model for steam coal purchasing strategy: A case study of Taiwan Power Company. Journal of Purchasing and Supply Management Vol. 22, pp. 131-140.

Jeng-Wen, L. and Chia-Yon, C. 1996. A cost minimization model for coal import strategy. Energy Policy Vol. 24, Issue 12, pp. 1111-1117.

KAMIŃSKI, J. and SAlUGA, P. 2014. Steam coal supplies for power generation - the concept of a mathematical model (Pozyskanie surowców energetycznych na potrzeby wytwarzania energii elektrycznej - koncepcja budowy modelu matematycznego). Gospodarka Surowcami Mineralnymi-Mineral Resources Management Vol. 30, Issue 1, pp. 39-52 (in Polish).

KAMIŃSKI, J. 2018. Supporting decision-making process in the fuel and energy industry with mathematical programming (Wsparcie procesu podejmowania decyzji w sektorze paliwowo-energetycznym $z$ wykorzystaniem programowania matematycznego). Publishing House of the MEERI PAS, Kraków. Kraków, pp. 181 (in Polish).

LiU C.-M. 2008. A Blending and Inter-Modal Transportation Model for the Coal Distribution Problem. International Journal of Operations Research Vol. 5, No. 2, pp. 107-116.

MaLeC et al. 2016 - MALEC, M., KAMIŃSKI, J. and KASZYŃSKI, P. 2016. Environmental regulations in the energy sector and demand for the hard coal (Regulacje środowiskowe wenergetyce a zapotrzebowanie na węgiel kamienny). Polityka Energetyczna - Energy Policy Journal Vol. 19, Issue 1, pp. 21-34 (in Polish).

Ministry of the Environment 2019. Announcement of the Minister of the Environment of October 3, 2018 on fees for using the environment for 2019 (Obwieszczenie Ministra Środowiska z dnia 3 października 2018 r. w sprawie wysokości stawek opłat za korzystanie ze środowiska na rok 2019) (in Polish).

RóG, L. 2006. The impact of factors resulting from the quality of fuel on the combustion process in power boilers (Wpływ czynników wynikających z jakości paliwa na proces spalania w kottach energetycznych) Proceedings of the Conference „Nowoczesne technologie spalania węgla i paliw odpadowych” (Modern technologies of burning coal and waste fuels), Szczyrk, pp. 211-225 (in Polish).

Suwala et al. 2015 - Suwala, W., KudeŁko, M., Olkuski, T., Szurlej, A. and Wyrwa, A. 2015. Principles of optimization of supplies for mineral and energy industries (Zasady optymalizacji dostaw surowców dla przedsiębiorstw sektora mineralnego i energetycznego). Zeszyty Naukowe Instytutu Gospodarki Surowcami Mineralnymi i Energia PAN No. 90, pp. 47-56 (in Polish).

Yucekaya, A. 2013. Cost Minimizing Coal Logistics for Power Plants Considering Transportation Constraints. Journal of Traffic and Logistics Engineering Vol. 1, No. 2, pp. 122-127.

YuCEKAYA, A. 2015. Managing Fuel Coal Supply Chains With Multiple Objectives and Multimode Transportation. Engineering Management Journal Vol. 25, No. 1, pp. 58-70.

WojtKowska-ŁodeJ, G. 2014. Climate and energy challenges and the European Union's policy (Wyzwania klimatyczne i energetyczne a polityka Unii Europejskiej). Polityka Energetyczna - Energy Policy Journal Vol. 17, Issue 2, pp. 39-52 (in Polish).

WojtKowsKa-ŁodeJ, G. and Nyga-ŁukASZEWSKA, H. 2018. Low-emission development strategies in the countries of Central and Eastern Europe (Strategie niskoemisyjnego rozwoju w krajach Europy Środkowo-Wschodniej, Raport SGH). XXVIII Forum Ekonomiczne w Krynicy. [Online] http://www.sgh.waw. pl/pl/Documents/raport_sgh/rozwoj-niskoemisyjny.pdf [Accessed: 2019-04-05] (in Polish). 


\title{
Koncepcja budowy modelu dostaw węgla kamiennego do energetyki zawodowej w aspekcie wybranych regulacji środowiskowych
}

\begin{abstract}
Streszczenie
Wdrażanie regulacji środowiskowych dla sektora energetycznego w krajach członkowskich Unii Europejskiej stanowi duże wyzwanie dla funkcjonowania jednostek wytwórczych energetyki zawodowej. Główną rolę odgrywają dokumenty takie jak tzw. Pakiet Zimowy czy Dyrektywa Parlamentu Europejskiego i Rady UE w sprawie ograniczenia emisji niektórych zanieczyszczeń do powietrza i wdrożenie konkluzji BAT służące kontynuacji kierunku polityki dekarbonizacyjnej. Regulacje te nakładają większą potrzebę kontroli substancji szkodliwych emitowanych do atmosfery przy spalaniu paliw kopalnych, w tym węgla kamiennego, który jest podstawowym paliwem krajowych jednostek. Jednocześnie spadek krajowego wydobycia paliw kopalnych, kierowanych do jednostek wytwórczych energii elektrycznej oraz wzrost zawartości pierwiastków szkodliwych w węglach kamiennych stanowi problem przy konieczności pozyskania odpowiedniej jakości paliwa i w konsekwencji prowadzi do wzrostu kosztów użytkowania węgla kamiennego. W artykule przedstawiono koncepcję budowy modelu matematycznego, którego celem jest odpowiedni dobór paliwa już na etapie planowania jego pozyskania co da możliwość redukcji tych kosztów. Zaletami proponowanego narzędzia, oprócz minimalizacji kosztu zakupu i użytkowania węgli, dla przedsiębiorstwa posiadającego własne zasoby węgla kamiennego może być także racjonalne gospodarowanie surowcami. W kolejnych krokach przedstawiona koncepcja będzie transponowana do postaci matematycznej modelu, czyli zestawu równań, nierówności i bilansów, co po zaimplementowaniu modelu w środowisku modelowania, wprowadzeniu danych wejściowych oraz opracowaniu scenariuszy badawczych pozwoli na rozwiązanie problemu badawczego.
\end{abstract}

SŁowA KLUCZOWE: energetyka, modelowanie matematyczne, regulacje środowiskowe, węgiel kamienny, konkluzje BAT 